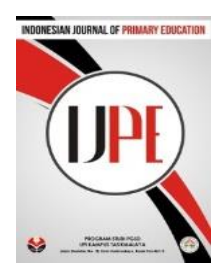

\title{
Modul Pendamping Pembelajaran Tematik Berbasis Kearifan Lokal Blitar di Kelas IV SD
}

\author{
Ludvi Novisatul Chusna ${ }^{1}$, Dyah Worowirastri Ekowati ${ }^{2}$, Kuncahyono ${ }^{3}$
}

SDN Gadungan 02 Blitar $^{1}$, Pendidikan Guru Sekolah Dasar, Universitas Muhammadiyah Malang 2,3

*Corresponding author: ludvichusna@gmail.com ${ }^{1}$, worowirastri@umm.ac.id ${ }^{2}$, kuncahyono@umm.ac.id ${ }^{3}$

Diterima 25 April; 2019; Direview 15 Mei 2019; Diterima 29 Mei 2019

Diterbitkan online 25 Juni 2019

\begin{abstract}
Introducing local wisdom to students needs to be done. The introduction of local wisdom can be supported by the existence of learning resources in the form of teaching materials. Information can be obtained by students independently, one of which is through the companion module. This research wielded research and development thesis by means of employing the ADDIE (Analyze, Design, Develop, Implementation, and Evaluation) approach. The purpose of this develop was to create the product of the companion module Thematic Companion Module under the theme "My Living Area" and subtheme "The Uniqueness of My Living Area by Using Blitar's Local Wisdom”. The final result of the expert's validation regarding teaching material module companion that was expanded by researcher, it has validity level of $96.66 \%$ from the material aspect, 90\% in the teaching material aspect, and 90\% in the learning aspect. Based on the above result, produce the products in the form of companion module teaching materials containing Blitar's local wisdom that highlight the regional conditions, history, arts, economic activities, and tourism sites which are equipped with folklore from Blitar, exercises, independent tests and evaluation questions has very valid, very good, very interesting to use in learning so that it can increase motivation and help learning in grade IV elementary school.
\end{abstract}

Keywords: Blitar's local wisdom, Companion Modul, Thematic Learning.

\begin{abstract}
Abstrak
Mengenalkan kearifan lokal daerah kepada peserta didik perlu untuk dilakukan. Pengenalan kearifan lokal dapat didukung dengan adanya sumber belajar berupa bahan ajar. Informasi dapat diperoleh oleh peserta didik secara mandiri, salah satunya melalai modul pendamping. Penelitian ini merupakan penelitian dan pengembangan dengan menggunakan jenis pendekatan ADDIE yaitu analisis, perancangan, pengembangan, penerapan, evaluasi. Tujuan pengembangan ini adalah untuk menghasilkan produk modul pendamping tematik yaitu Modul Tematik Tema Daerah Tempat Tinggalku Berbasis Kearifan Lokal Blitar. Hasil validasi ahli bahan ajar modul pendamping yang dikembangkan yaitu dengan tingkat kevalidan 96,66\% dari aspek materi, 90\% dalam aspek bahan ajar, dan 90\% dalam aspek pembelajaran. Berdasarkan hasil tersebut, pengembangan ini menghasilkan produk berupa bahan ajar modul pendamping pembelajaran tematik berbasis kearifan lokal Blitar yang menonjolkan kondisi wilayah, sejarah, kesenian, kegiatan ekonomi, dan tempat wisata yang dilengkapi dengan cerita rakyat dari Blitar, latihan soal, tes mandiri serta soal evaluasi dengan kriteria sangat valid, sangat baik, sangat menarik dan sangat bermanfaat sehingga dapat meningkatkan motivasi dan membantu pembelajaran di kelas IV SD.
\end{abstract}

Kata Kunci: Kearifan Lokal Blitar, Modul Pendamping, Pembelajaran Tematik.

\section{PENDAHULUAN}

Pembelajaran tematik merupakan sebuah terjadinya proses pembelajaran dengan menggabungkan dua atau lebih muatan pelajaran ke dalam satu tema. Berdasarkan Permendikbud No. 57 tepatnya pada tahun 2014 yang membahas tentang pembelajaran tematik, mengartikan sebagai suatu pembelajaran yang terpadu yang berarti menjadikan tema sebagai penghubung antara beberapa mata pelajaran menjadi satu pokok bahasan yang termuat dalam sebuat tema, sehingga dalam tema tersebut peserta didik memperoleh pengalaman belajar yang bermakna (Permendikbud, 2014). Trianto (2011) berpendapat, pembelajaran tematik 
diartikan sebagai sebuah model pembelajaran dengan cara menyatukan dua atau lebih dari satu muatan materi pembelajaran yang memenuhi standar kompetensi dan kompetensi dasar yang diharapkan dalam beberapa mata pelajaran yang digabungkan. Hal ini sesuai dengan fakta dilapangan, bahwa proses pembelajaran di SDN Gadungan 02, Blitar telah ditematikkan.

Pelaksanaan pembelajarannya, hendaknya menggunakan berbagai sumber belajar sebagai bahan pedomann dalam pembelajaran. Warsita (2008) berpendapat bahwa, adanya suatu proses pembelajaran yang memanfaatkan lebih dari satu sumber belajar, dapat mempengaruhi terhadap kualitas pembelajaran. Salah satu bentuk sumber belajar yaitu bahan ajar. Prastowo (2015) menyampaikan bahwa, bahan ajar merupakan segala bentuk atau bahan yang disusun dengan runtut yang didalamnya menyampaikan kompetensi secara utuh yang dalam kegiatan pembelajaran akan dipelajari oleh peserta didik, yang disusun sesuai dengan tujuan perencanaan pelaksanaan pembelajaran, seperti modul LKPD, buku, dan sebagainya.

Berdasarkan hasil pengamatan yang dilakukan pada saat observasi dan wawancara awal dengan guru kelas IV pada tanggal 27 dan 30 Oktober 2018 di SDN Gadungan 02 Blitar, selama proses pembelajaran di kelas guru maupun peserta didik telah memanfaatkan dan menggunakann buku guru dan buku siswa yang dikeluarkan dan dibuat oleh pemerintah. Selain dengan memenfaatkan buku guru dan buku siswa, selama proses pembelajaran juga telah menggunakan buku pendamping seperti LKS, namun penggunaan bahan ajar tersebut dalam proses pembelajaran dirasa masih kurang. Kenyataannya, di dalam buku guru, buku siswa maupun buku pendamping LKS yang digunakan dalam pembelajaran masih bersifat umum, dan belum menunjukkan adanya unsur lingkungan dan budaya setempat, akibatnya peserta didik kurang dalam memahami dan mengetahui macam-macam kearifan lokal budaya di sekitar mereka, sedangkan pada beberapa kompetensi dasar di kelas IV menuntut peserta didik untuk memehami kearifan lokal mereka sendiri.

Temuan lain yang diperoleh yaitu buku siswa yang mereka pakai belum dimiliki secara pribadi oleh peserta didik, serta belum adanya muatan kearifan lokal Blitar di dalam LKS yang mereka gunakan. Sebagaian peserta didik menyatakan bahwa terkadang mengalami kesulitan pada saat mengerjakan soal yang terdapat dalam buku siswa dikarenakan muatan materi yang terdapat dalam buku siswa terbatas. Sebagaian dari peserta didik berpendapat bahwa dalam buku siswa terdapat banyak latihan soal yang menuntut mereka untuk menemukan dan menjawab pertanyaan di luar materi yang ditampilkan di buku siswa, sehingga peserta didik harus mencari buku pendamping lain 
untuk membantu mereka menyelesaikan pertanyaan.

Terkait dengan penggunaan bahan ajar, peserta didik meyebutkan bahwa belum pernah menggunakan buku yang di dalamnya memuat kearifan lokal Blitar. Berdasarkan apa yang diketahui oleh peserta didik, materi yang sering mereka lihat dan temukan di dalam buku, sering memuat kearifan lokal daerah lain dan bukan daerah Blitar sendiri. Saat di wawancara mengenai makanan khas Blitar, peserta didik tidak menyadari bahwa makanan yang sering mereka makan merupakan makanan khas daerahnya. Hal tersebut membuktikan bahwa peserta didik belum banyak mengetahui tentang kearifan lokal Blitar.

Kearifan lokal begitu melekat dengan ciri khas yang ada pada suatu daerah. Potensi yang dimiliki suatu daerah yang dapat dimanfaatkan dan diolah menjadi suatu barang atau jasa yang sangat bernilai untuk menambah penghasilan daerah yang memiliki keunikan serta memiliki keunggulan yang dapat bersaing dengan daerah lain disebut sebagai kearifan lokal. Menurut Mumpuni (2013), kearifan lokal atau yang sering disebut dengan budaya lokal, merupakan budaya asli yang berasal dan berkembang pada masyarakat di suatu daerah, sehingga kearifan lokal ini menggambarkan ciri khas dari suatu daerah tertentu. Kearifan lokal daerah, perlu untuk sedini mungkin dikenalkan kepada peserta didik. Menurut
Hidayat (2013), adanya ketidaktahuan peserta didik terhadap kearifan lokal budaya daerah sendiri, mengakibatkan tujuan pendidikan tidak tersampaikan dengan baik, sehingga mengakibatkan tidak adanya pelestarian serta eksistensi dari generasi penerus terhadap kearifan lokal untuk di pelajari dan dimasukkan dalam proses pendidikan ataupun dalam praktik di kehidupan sehari-hari.

Berdasarkan hal itu, dapat disimpulkan bahwa untuk mengenalkan kearifan lokal ini guru perlu memasukkan materi yang menggunakan kearifan lokal dalam proses pembelajaran, supaya peserta didik dapat mempertahankan pengetahuan daerah dalam menghadapi perkembangan serta kemajuan pendidikan terhadap ciri khas budaya yang dimiliki daerah disekitarnya. Suatu proses pembelajaran yang memanfaatkan sumber belajar, akan mempengaruhi kualitas pembelajaran (Warsita, 2008), sehingga dengan tersedianya sumber belajar yang lebih banyak akan memberi kemudahan peserta didik untuk lebih mengetahui sebuah pengetahuan atau konsep serta memberi motivasi untuk memperluas wawasan guna mencapai tujuan pembelajaran yang diharapkan. Menurut Ekowati (2017), budaya lokal berfungsi sebagai sarana dalam menyampaikan pembelajaran dengan lebih menekankan kepada tercapainya sebuah pemahaman yang terpadu daripada pemahaman mendalam. 
Bahan ajar buku siswa yang digunakan dan dimiliki secara pribadi oleh peserta didik adalah buku pendamping LKS. Adapun buku siswa, untuk sementara ini masih dipinjami oleh sekolah. Peserta didik dalam menyelesaikan tugas yang berhubungan dengan daerah sekitar (kearifan lokal Blitar), selama ini belum menggunakan bahan ajar yang memadai, karena belum terdapat bahan ajar yang memuat kearifan lokal Blitar yang dapat dipakai maupun dipinjam oleh peserta didik di luar jam pembelajaran. Sehingga seringkali peserta didik belum dapat menyelesaikan tugas dan belum bisa secara mandiri memperluas wawasan dengan membaca buku tentang kearifan lokal Blitar di luar jam pembelajaran.

Berdasarkan permasalahan terkait dengan sumber belajar tersebut, maka diperlukan tambahan bahan ajar sebagi penunjang dalam proses pembelajaran. Segala bentuk bahan yang memiliki fungsi dan memberi manfaat untuk membantu guru dalam menjalankan proses belajar mengajar disebut dengan istilah bahan ajar (Majid, 2008). Salah satu bentuk bahan ajar yang dapat digunakan guru dalam menyampaikan materi pembelajaran dalam tematik dengan tujuan menambah wawasan peserta didik serta melatih kemandirian, yaitu dapat memanfaatkan modul pendamping. Adanya modul pendamping pembelajaran tematik diharapkan, guru dapat terbantu dalam menyampaikan materi terkait dengan keunikan daerah setempat guna menambah wawasan pengetahuan peserta didik, serta dapat dimanfaatkan untu melatih kemandirian belajar bagi peserta didik, karena jenjang kelas IV ini merupakan jenjang mereka mulai belajar mandiri, sesuai dengan salah satu sifat modul yang berdiri sendiri dan dan dapat digunakan secara mendiri oleh peserta didik, diharapkan bahan ajar modul dapat digunakan juga oleh peserta didik di luar jam pelajaran.

Modul memiliki kegunaan dalam pembelajaran seperti yang diungkapkan oleh Belawati (2003), bahwa modul sebagai penyedia informasi dasar, karena di dalam modul menyajikan materi pokok yang dapat dikembangkan lebih lanjut lagi, yaitu berperan sebagai bahan petunjuk bagi peserta didik, digunakan sebagai bahan ajar pelengkap yang dilengkapi dengan ilustrasi dan foto yang komunikatif, sebagai petunjuk mengajar bagi guru serta terdapat bahan latihan untuk peserta didik. Sejalan dengan pendapat tersebut, Mulyasa berpendapat bahwa modul dalam suatu proses pembelajaran memiliki kekhasan yaitu berisi tentang suatu pokok bahasan tertentu, disusun secara runtut atau sistematis, operasional dan terarah bagi peserta didik yang dilengkapi dengan adanya petunjuk penggunaannya. Sependapat dengan hal tersebut, dapat disimpulkan bahwa modul merupakan sebuah buku yang memuat adanya kegiatan dan latihan yang memungkinkan peserta didik belajar dan mencapai tujuan pembelajaran, yang mana hal tersebut dapat 
dicapai melalui soal latihan dan dapat dilihat keberhasilannya melalui soal evaluasi dengan memperhatikan penggunaan bahasa yang baik, mudah dipahami, dan dilengkapi dengan ilustrasi gambar, sehingga dapat dipelajari secara mandiri. Berdasarkan hal tersebut, artikel ini akan membahas mengenai pengembangan yang berjudul "Modul Pendamping Pembelajaran Tematik Berbasis Kearifan Lokal Blitar di Kelas IV SD”. Modul pendamping pembelajaran tematik ini secara garis besar dilengkapi dengan petunjuk penggunaan modul, materi-materi, gambar, latihan-latihan soal, soal evaluasi, glosarium, daftar pustaka serta adanya kunci jawaban soal.

\section{METODE PENELITIAN}

Model pengembangan yang digunakan untuk mengembangkan modul pendamping berbasis kearifan lokal Blitar ini yaitu dengan model ADDIE. Model prosedural ADDIE ini dijabarkan kedalam lima langkah yaitu Analyze, Design, Develop, Implementation, Evaluation (analisis, perancangan, pengembangan, implementasi dan evaluasi). Model ADDIE dikembangkan secara sistematis (terstruktur) yang artinya terprogran dengan urut sebagai upaya dari pemecahan masalah belajar peserta didik yang berhubungan dengan sumber belajar yang dibutuhkan dan kerakteristik peserta didik. Penggunaan model ADDIE digunakan untuk melakukan pengembangan produk contohnya buku ajar untuk pembelajaran, modul pembelajaran, video pembelajaran, mutimedia, dan lain sebagainya (Tegeh, 2004). Penelitian pengembangan disebut juga Research and Development (R\&D) yaitu suatu cara atau sebuah metode penelitian yang efektif untuk memperbaiki sebuah praktik, yang dilakukan dengan cara menyempurnakan produk yang sudah ada atau membuat suatu produk baru yang dapat dipertanggung jawabkan (Sukmadinata, 2013).

\section{Tahap ADDIE}

Tahap analisis yang dilakukan dalam proses pengembangan produk meliputi kegiatan melakukan analisis kompetensi dasar yang diharapkan untuk dicapai oleh peserta didik, analisis terhadap kebutuhan peserta didik saat proses pembelajaran, analisis terkait dengan karakteristik peserta didik selama mengikuti proses pembelajaran. Tahap perancangan dilakukan dengan membuat kerangka modul dan menentukan desain, KD, indikator, tujuan pembelajaran, serta materi. Tahap pengembangan dilakukan dengan membuat draft awal, sehingga menghasilkan rancangan produk pengembangan modul pendamping. Setelah draft awal selesai dibuat dan sebelum di uji cobakan, akan dilakukan validasi oleh validator yang ahli dalam pengembangan produk yaitu dilakukan kepada 1) ahli materi, 2) ahli bahan ajar, dan 3) ahli pembelajaran. melalui tahap validasi, kemudian dilanjutkan dengan tahap implementasi yang dilakukan dengan kegiatan menerapkan produk berupa modul pendamping yang telah dikembangkan kepada 34 peserta didik kelas IV SD di SDN 
Gadungan 02, Blitar untuk mengetahui kemenarikan dan kebermanfaatan modul pendamping tematik, dengan harapan produk yang dikembangkan dapat memperluas wawasan peserta didik terkait dengan kearifan lokal Blitar, membantu memberikan motivasi belajar peserta didik, dan membantu guru dalam mengenalkan kearifan lokal Blitar kepada peserta didik. Pada tahapan evaluasi dan perbaikan, telah dimulai sejak tahap analsis yaitu setiap adanya saran dan masukan untuk melakuan perbaikan terhadap modul yang dikembangkan. Tujuan dari tahap evaluasi adalah untuk menyempurnakan produk serta mengetahui tingkat kelayakan produk. Pada setiap tahapannya, model ADDIE ini akan memberikan kesempatan untuk mengevaluasi setiap kegiatan pengembangan produk, dengan tujuan untuk memperkecil adanya tingkat kekurangan atau kesalahan pada produk yang dikembangkan (Piskurich, 2000). Adapun kriteria pencapaian dalam pengembangan modul tematik berbasis kearifan lokal Blitar sebagai berikut:

Tabel 1

\section{Kualifikasi Tingkat Pencapaian}

\begin{tabular}{|c|c|c|c|}
\hline No. & $\begin{array}{c}\text { Pencapaian } \\
(\%)\end{array}$ & $\begin{array}{c}\text { Tingkat } \\
\text { Validitas }\end{array}$ & Keterangan \\
\hline 1 & $\begin{array}{c}81,00- \\
100,00 \%\end{array}$ & $\begin{array}{l}\text { Sangat } \\
\text { valid }\end{array}$ & $\begin{array}{l}\text { Dapat digunakan } \\
\text { tanpa revisi }\end{array}$ \\
\hline 2 & $\begin{array}{c}61,00- \\
80,00 \%\end{array}$ & Valid & $\begin{array}{l}\text { Dapat digunakan } \\
\text { dengan sedikit } \\
\text { revisi }\end{array}$ \\
\hline 3 & $\begin{array}{c}41,00- \\
60,00 \%\end{array}$ & $\begin{array}{l}\text { Cukup } \\
\text { valid }\end{array}$ & $\begin{array}{l}\text { Dapat digunakan } \\
\text { namun perlu } \\
\text { direvisi cukup besar }\end{array}$ \\
\hline 4 & $\begin{array}{c}21,00- \\
40,00 \%\end{array}$ & $\begin{array}{l}\text { Kurang } \\
\text { valid }\end{array}$ & $\begin{array}{l}\text { Kurang layak, perlu } \\
\text { direvisi besar }\end{array}$ \\
\hline 5 & $\begin{array}{c}00,00- \\
20,00 \%\end{array}$ & $\begin{array}{l}\text { Tidak } \\
\text { valid }\end{array}$ & $\begin{array}{l}\text { Tidak layak, dan } \\
\text { perlu untuk direvisi } \\
\text { sangat besar }\end{array}$ \\
\hline
\end{tabular}

Sumber: Akbar (2017), dengan modifikasi

\section{Teknik Analisis Data}

Teknik analisis data yang digunakan untuk mengolah data ini yaitu menggunakan analisis data deskriptif kualitataif dan analisis data kuantitatif. Teknik analisis data kualitatif, dilakukan untuk menganalisis data berupa hasil observasi, wawancara, saran maupun kritik yang diberikan oleh berbagai macam pihak serta ahli dalam validasi modul pendamping tematik yang dikembangkan. Hasil dari analisis akan digunakan sebagai bahan untuk merevisi atau memperbaiki modul pendamping pembelajaran tematik tema daerah tempat tinggalku berbasis kearifan lokal Blitar yang sedang dikembangkan. Analisis data kuantitatif dilakukan dengan menghimpun data yang berasal dari penilaian angket, baik angket untuk validator yaitu kepada ahli materi, ahli bahan ajar, dan ahli pembelajaran.

\section{HASIL DAN PEMBAHASAN}

Pengetahuan serta wawasan terhadap daerah perlu untuk diketahui dan dipahami oleh peserta didik dengan tujuan menumbuhkan rasa bangga serta rasa memiliki terhadap warisan budaya yang ada pada daerahnya, sehingga pengenalan terhadap budaya daerah penting untuk diberikan kepada peserta didik. Pengetahuan atau konsep tentang daerah dapat dikenalkan melalui bahan ajar yang digunakan dalam kegiatan pembelajaran. Prastowo (2015) berpendapat bahwa dengan adanya bahan ajar yang menarik, dapat memberikan lebih banyak kesempatan kepada peserta didik 
untuk belajar secara mandiri dengan bimbingan pendidik, dan memberi kemudahan peserta didik untuk memahami setiap kompetensi yang harus dipahami. Pendapat ini didukung oleh penelitian yang dilakukan oleh Su'udiah (2016), yang menghasilkan buku suplemen berbentuk buku teks tematik dengan berbasis kontekstual dalam pengembangan subtema "Keunikan Daerah tempat Tinggalku" yang memiliki kevalidan, menarik untuk digunakan, praktis dan efektif saat digunakan dalam pembelajaran.

Tahap analisis merupakan tahap yang dilakukan oleh peneliti untuk mengumpulkan informasi sebagai dasar dalam melakukan sebuah penelitian pengembangan. Berdasarkan data yang diperoleh peneliti dari kegiatan observasi dan wawancara di SDN Gadungan 02, Blitar di kelas IV SD, dapat disimpulkan bahwa perlu adanya pengembangan Modul Pendamping Pembelajaran Tematik untuk mengenalkan Kearifan Lokal Blitar yang dapat digunakan dalam Tema Daerah Tempat Tinggalku khususnya pada subtema Keunikan Daerah Tempat Tinggalku di Kelas IV SD yang selain untuk membantu guru menyampaikan materi, tetapi juga dapat digunakan untuk menambah wawasan peserta didik terhadap daerahnya sehingga adanya kesinambuangan ilmu pengetahuan peserta didik dengan materi yang ada di buku pemerintah dan materi yang perlu untuk dikuasai oleh peserta didik. Pada tahap ini, dilakukan pendalaman terhadap beberapa aspek yang akan menentukan kebutuhan pengembangan yang diperoleh dari berbagai sumber informasi.

Pada tahap selanjutnya, yaitu tahap perencanaan pengembangan, dilakukan dengan menentukan desain yaitu desain secara garis besar terkait dengan produk pengembangan yang akan dibuat. Desain ini ditentukan setelah melakukan tahap analsis dengan mengetahui kebutuhan guru dan peserta didik dalam kegiatan pembelajaran, sehingga digunakan untuk menentukan rancangan pembuatan sebuah modul pendamping tematik yang dibutuhkan. Pada tahap perencanaan ini, dilakukan dengan analisis Kompetensi Dasar, indikator, dan garis materi di setiap pembelajaran yang dipadu-padankan dalam tema daerah tempat tinggalku subtema keunikan daerah tempat tinggalku dengan kegiatan pembelajaran berdasarkan analisis kebutuhan pada kegiatan observasi dan wawancara yang dilakukan bersama guru dan peserta didik dalam kegiatan pembelajaran. Rancangan produk bahan ajar yang akan dikembangkan, meliputi tampilan dan isinya. Hal ini didukung oleh pendapat Trianto (2011), bahwa dengan pelaksanaan kurikulum 2013 yang berbentuk tematik dan di dukung dengan adanya tema, akan memberi kemudahan kepada peserta didik dan guru untuk memfokuskan perhatian dan materi kedalam lingkup yang jelas dan memberikan kebermanfaatan dan 
kebermaknaan. Sukandi (2003) berpendapat, pembelajaran tematik terpadu pada dasarnya sebagai bentuk kegiatan pembelajaran dengan menggabungkan lebih dari satu materi pelajaran ke dalam satu tema.

Berikut uraian singkat tahap pembuatan dan hasil validasi produk yang dikembangkan:

a) Tahap Pembuatan

Tahap pembuatan Modul Pendamping Pembelajaran Tematik Tema Daerah Tempat Tinggalku Berbasis Kearifan Lokal Blitar dengan mengikuti langkah pembuatan modul Daryanto (2013) yaitu 1) Menentukan Kompetensi Dasar, Indikator, tujuan, dan garis besar materi. 2) Menentukan materi yang sesuai dengan KD, Indikator, Tujuan, dan Garis besar materi kearifan lokal Blitar ke dalam masing-masing pembelajaranyang terdapat pada tema tersebut. 3) Menentukan jenis tulisan, ukuran, dan gambaran sampul yang akan digunakan. 4) Mencari bahan yang akan dimasukkan ke dalam modul baik dalam memilah dan memilih gambar, materi-materi, bacaan, dsb yang sesuai dengan materi utama yang dimasukkan ke dalam modul pendamping. 5) Mendesain background dalam setiap bagian modul (pembatas bab dalam setiap pembelajaran), serta membuat sampul. 6) Menyusun tata letak gambar, tulisan, cerita serta urutan yang ada pada modul.7) Membuat soal tes mandiri, kunci jawaban tes mandiri dan cara penilaian. 8) Membuat soal evaluasi, kunci jawaban evaluasi serta glosarium, daftar isi, dan daftar gambar. 9) Mencetak modul dan cover yang telah di desain dalam bentuk print out.

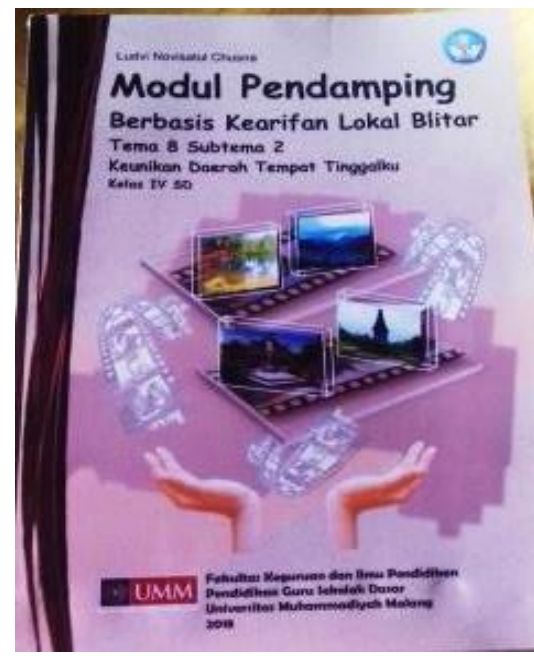

Gambar 1

Produk Modul pendamping pembelajaran tematik berbasis kearifan lokal Blitar

Anwar (2017) mengungkapkan bahwasannya, tujuan dari pengenalan budaya lokal kepada peserta didik yaitu supaya lebih mencintai budaya lokal yang ada di daerahnya serta peserta didik mengetahui makna dan perbedaan ketika membandingkannya dengan budaya daerah lain. Tidak hanya itu, pendapat ini juga didukung oleh Hidayat (2013), bahwa masing-masing daerah memerlukan pendidikan yang sesuai dengan karakteristik daerah dan pengalaman hidup sehari-hari, yang mana setiap daerah memiliki potensi, kebutuhan, tantangan dan keragaman karakteristik lingkungan, sehingga muatan kearagaman tersebut berguna untuk menghasilkan lulusan yang relevan dengan kebutuhan pengembangan daerah.

b) Tahap Validasi

Pengembangan modul pendamping pembelajaran tematik ini divalidasi oleh 3 ahli 
yang memiliki kemampuan untuk memvalidasi yaitu ahli materi, ahli bahan ajar, serta ahli pembelajaran. Para validator ini bertujuan untuk memberikan nilai terhadap modul pendamping yang dibuat atau dikembangkan. Berdasarkan hasil penilain serta kritik maupun saran yang didapatkan dari validator produk yang dikembangkan tersebut, akan menjadi sumber acuan dalam memperbaiki modul pendamping berbasis kearifan lokal Blitar yang dikembangkan, sehingga produk yang dikembangkan akan diperbaiki hingga memenuhi syarat kevalidan dan layak untuk digunakan.

Tabel 2

Hasil Penilaian Kelayakan Produk oleh Para Ahli

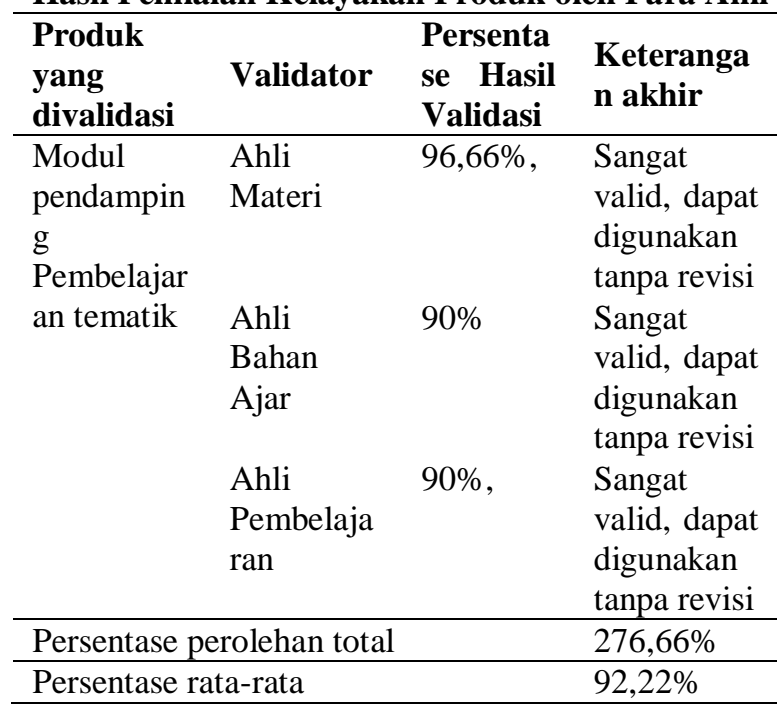

Sumber : olahan peneliti

Berdasarkan Tabel 1. diketahui rata-rata persentase yang diperoleh dari ketiga ahli validator sebesar $92,22 \%$ yang berarti bahan ajar yang dikembangkan sangat valid, dapat digunakann tanpa revisi sehingga layak untuk digunakan. Akan tetapi, perbaikan dan revisi tetap dilakukan berdasarkan saran yang diberikan oleh validator supaya produk yang dikembangkan semakin baik lagi.
Selama kegiatan implementasi dilakukan dengan kegiatan observasi yaitu melakukan pengamatan selama kegiatan pembelajaran berlangsung dengan tujuan mengetahui antusias peserta didik dalam memanfaatkan modul pendamping, serta melihat motivasi yang terbangun pada saat menggunakan modul pendamping kearifan lokal Blitar ini melalui lembar observasi yang telah disediakan. Implementasi modul pendamping yang dibuat untuk diterapkan di SDN Gadungan 02 pada kelas IV, yang sebelumnya telah dilakukan validasi untuk menilai kelayakan dari modul dan penyusunannya sesuai dengan karakteristik modul yaitu self instruction, self contained, stand alone, adaptif, dan user friendly. Hal ini didukung oleh pendapat Mulyasa (2008), bahwa penggunaan modul dalam proses pembelajaran berisi tentang suatu pokok bahasan yang disusun secara sitematis atau runtut, operasional dan terarah bagi peserta didik serta dilengkapi dengan petunjuk penggunaan.

Berdasarkan hasil pengamatan saat implementasi, terlihat bahwa peserta didik maupun guru antusias dalam menggunakan modul pendamping pembelajaran tematik ini selama kegiatan pembelajaran berlangsung. Pada tahap implementasi tersebut terlihat adanya keaktifan peserta didik untuk menyelesaikan tugas yang diberikan oleh guru, berinteraksi mengajukan diri untuk mengikuti kegiatan pembelajaran seperti 
membaca, menjawab pertanyaan guru, membaca cerita daerah Blitar ataupun bacaan yang terdapat dalam modul. Adapun guru juga menunjukkan lebih bersemangat dalam menyampaikan materi karena didukung dengan adanya tambahan bahan ajar yang dapat dijadikan sebagai referensi tambahan bagi peserta didik, yang memuat unsur daerah Blitar yang sejauh ini masih minim diketahui oleh peserta didik. Sependapat dengan Anwar (2017), bahwasannya tujuan dari pengenalan budaya lokal adalah supaya peserta didik lebih mencintai budaya lokal di daerahnya serta mengetahui makna perbedaan ketika membandingkannya dengan budaya daerah lain. Berrdasarkan pendapat tersebut, dapat disimpulkan bahwa dengan pengenalan budaya, peserta didik belajar untuk mengapresiasi budaya daerahnya sendiri.

Penerapan modul pendamping tematik ini dirancang sedemikian rupa dengan harapan peserta didik memiliki kesempatan untuk belajar mandiri dan bertanggung jawab terhadap apa yang dilakukan atau dikerjakannya. Selain itu dalam penerapannya menunjukkan bahwa peserta didik antusias dan termotivasi saat mengikuti kegiatan pembelajaran. Temuan ini sependapat dengan Majid (2008), bahwa modul merupakan sebuah buku yang ditulis dengan memberikan kesempatan kepada peserta didik untuk dapat menggunakannya untuk belajar mandiri tanpa atau dengan bimbingan guru yang dilengkapi dengan adanya petunjuk penggunaan.
Didukung juga dengan pendapat Prastowo (2015), bahwa peserta didik memiliki kesempatan untuk menyelesaikan lebih dari satu kompetensi dasar sesuai dengan kemampuannya sebagai bahan berlatih.

Tahap evaluasi telah dilakukan mulai dari proses perencanaan pembuatan dan pengembangan modul pendamping pembelajaran tematik yaitu dimulai dari tahap analisis, perencanaan, pengembangan serta implementasi. Kegiatan evaluasi dilakukan setiap kali ada saran dan kritik dari berbagai pihak untuk memperbaiki kekurangan yang ada pada modul yang sedang dikembangkan, bertujuan untuk memenuhi kebutuhan untuk menyempurnakan modul pendamping yang dibuat, serta menemukan solusi atas permasalahan atau kendala tersebut. Adapun kritik dan saran yang diberikan oleh validator maupun berbagai pihak tersebut, digunakan sebagai pertimbangan dalam melakukan perbaikan. Hal ini sependapat dengan Daryanto (2013), bahwa dari tahap awal hingga akhir pengembangan bahan ajar modul memiliki satu keterkaitan dan memberikan umpan balik, sehingga jika terdapat ketidaksesuaian dengan yang diharapkan, maka akan menjadi perbaikan dengan prinsip yang lain.

\section{SIMPULAN}

Pengembangan ini menghasilkan produk berupa Modul Pendamping Pembelajaran Tematik Berbasis Kearifan Lokal Blitar di Kelas IV SD yang mengkhususkan pada tema 
daerah tempat tinggalku subtema keunikan daerah tempat tinggalku dalam bentuk cetak. yang memuat pelajaran antara lain Bahasa Indonesia, IPA, IPS, PPKN dan SBdP sesuai dengan kurikulum 2013 yang berbentuk tematik. Adapun muatan materi yang terdapat dalm modul pendamping yang dikembangkan memuat kearifan lokal Blitar seperti letak geografis, ragam makna gerakan tari, kegiatan ekonomi, sejarah Blitar, pelestarian kesenian Blitar dan tempat wisata. Berdasarkan hasil validasi yang dilakukan kepada validator diperoleh data yaitu validator materi dengan persentase $96,66 \%$, validator bahan ajar sebesar $90 \%$ dan validator pembelajaran sebesar 90\%, sehingga dari ketiga validator tersebut maka modul pendamping yang dikembangan atau dibuat, memenuhi kriteria valid dan sangat layak untuk digunakan.

Berdasarkan hasil pengembangan yang telah dilakukan, maka saran yang diberikan selanjutnya yaitu modul pendamping pembelajaran tematik berbasis kearifan lokal Blitar dapat digunakan untuk sebagai bahan ajar tambahan dalam memahami kearifan lokal Blitar sebagai pendamping materi dalam pembelajaran tema daerah tempat tinggalku untuk subtema keunikan daerah tempat tinggalku ataupun dijadikan bahan ajar dalam subtema yang lain, selama masih berhubungan dan berkaitan dengan materi ini. Serta akan lebih efektif dan bermanfaat lagi bila modul pendamping ini digunakan sebagai bahan ajar di luar jam kelas, supaya dapat dimanfaatkann secara maksimal, serta diharapkan bagi peneliti selanjutnya untuk mengembangkan modul pendamping pembelajaran tematik berbasis kearifan lokal daerah lain dengan kompetensi inti dan kompetensi dasar yang lain.

\section{DAFTAR PUSTAKA}

Akbar, Sa'dun. 2017. Instrumen Perangkat Pembelajaran. Bandung: PT Remaja Rosdakarya.

Anwar, F. N, Ruminiati, \& Suharjo. 2017. Pengembangan Modul Pembelajaran Tematik Terpadu Berbasis Kearifan Lokal Kabupaten Sumenep Kelas IV Subtema Lingkungan Tempat Tinggalku. Jurnal Pendidikan, (Online), 2 (10): 1291-1297, (http://journal.um.ac.id/index.php/jptpp/ ), diaskses 28 Oktober 2018.

Belawati, A. 2003. Pengembangan Bahan Ajar. Jakarta: Universitas Terbuka.

Daryanto. 2013. Menyusun Modul Bahan Ajar untuk Persiapan Guru dalam Mengajar (Darmiyatun, S., Ed).Yogyakarta: Gava Media.

Depdiknas. 2014. Permendiknas No. 57 Tahun 2014 Tentang Pedoman Pembelajaran Tematik Terpadu. Jakarta: Depdiknas.

Ekowati, D. W., Kusumaningtyas, D. I, \& Sulistyani, N. 2017. Ethnomathematica. dalam Pembelajaran Matematika (Pembelajaran Bilangan dengan Media Batik Madura, Tari Khas Trenggal dan Tari Khas Madura. Jurnal Pemikiran dan Pengembangan SD. 5 (2): 716-722.

Hidayat, Sholeh. 2013. Pengembangan Kurikulum Baru (A.S. Wardan, Ed). Bandung: PT Rosdakarya. 
Majid, Abdul. 2008. Pengembangan Pembelajaran (Muhklis, Ed). Bandung: PT Rosdakarya.

Mulyasa, E. 2008. Kurikulum Berbasis Kompetensi. Bandung: PT Remaja Rosdakarya.

Mumpuni, K. E. 2013. Potensi Pendidikan Keunggulan Lokal Berbasis Karakter dalam Pembelajaran Biologi di Indonesia. Makalah disajikan pada Prosiding Seminar Nasional $X$ Pendidikan Biologi FIP UNS. (Online), (http://jurnal.fkip.uns.ac.id/index.php/pr osbio/article/), diakses pada 01 Oktober 2018.

Piskurich, George M. 2000. The ASTD handbook of Training Design and Delivery: A Comprehensive guide to Creating and Delivery Training Programs, Instructor-led, Computerbased, or Self-directed. United States: Mc Graw-Hill Professional.

Prastowo, Andi. 2015. Panduan Kreatif Membuat Bahan Ajar Inovatif Menciptakan Metode Pembelajaran yang Menarik dan Menyenangkan (D, Wijaya, Ed), Jogjakarta: Diva Press.

Su'udiah, F., Degeng, I. N. S., \& Kuswandi, D. 2016. Pengembangan Buku Teks Tematik Berbasis Kontekstual. Jurnal Pendidikan. (Online), 1 (9): 1744-1748, (http://journal.um.ac.id), diakses 2 Nopember 2018.

Sukandi, Ujang. 2003. Belajar Aktif dan Terpadu. Surabaya: Duta Graha Pustaka.

Sukmadinata, Nana Syaodih. 2013. Metode Penelitian Pendidikan. Bandung: PT Remaja Rosdakarya.

Tegeh, I., M., Jampel, I. N., Pudjawu, K. 2014. Model Penelitian Pengembangan. Yogjakarta: Graha Ilmu.
Trianto. 2011. Desain Pengembangan Pembelajaran Tematik Bagi Anak Usia Dini TK/RA \& Anak Usia Awal Kelas SD/MI (J. Alfin, Ed). Jakarta: Kencana.

$\begin{array}{ccr}\text { Warsita, Bambang. } & 2008 . & \text { Teknologi } \\ \text { Pembelajaran } & \text { Landasan } & \text { dan } \\ \text { Aplikasinya. Jakarta: Rineka Cipta. }\end{array}$

